Etikonomi

Volume 16 (2), Oktober 2017

P-ISSN: 1412-8969; E-ISSN: 2461-0771

Page 207 - 220

\title{
Entrepreneurial Government Attitude Towards The Performance of Local Government Officials
}

\author{
Agus Supandi Soegoto, Ritson Eras Kadisi \\ Sam Ratulangi University, Manado \\ supandi_smrt@yahoo.co.id, ritson.kadisi@yahoo.co.id
}

\begin{abstract}
Public demand for the implementation of good governance in the public sector for several years has been increasing because the performance of public services does not seem to meet public expectations. The purpose of this study is to determine the influence of entrepreneurial mental attitude on the performance of the government apparatus in the district of Sitaro Islands. The analytical method used is associative and relies on multiple linear regression. The results show that both simultaneously and partially, entrepreneurial government mental attitudes including innovator, brave and creative attitudes, creating value and recognizing opportunities, communication skills, buman mobility, and resource bave a positive and significant impact on the performance of government officials. The results also show the attitude of innovators has the lowest variable value which means that the leaders should enhance the attitude of Mental Entrepreneurial by improving the employees' attitude of innovators, either through leadership training, entrepreneurship, or education quality improvement, therefore the performance of the officials may be enhanced.
\end{abstract}

Keywords: entrepreneurial mental attitude, innovators, creating value, performance

\begin{abstract}
Abstrak
Tuntutan masyarakat terhadap pelaksanaan good governance pada sektor publik beberapa tabun ini semakin meningkat, karena kinerja pelayanan publik dirasakan belum memenubi harapan. Tujuan penelitian ini untuk mengetahui pengaruh sikap mental enterpreneurial terhadap Kinerja aparatur pemerintah di Kabupaten Kepulauan Sitaro. Metode analisis yang digunakan yaitu asosiatif. Teknik analisis menggunakan Regresi Linier Berganda. Hasil penelitian menunjukkan babwa secara simultan maupun parsial sikap mental enterpreneurial yaitu: Inovator; Sikap pemberani dan kreatif; Menciptakan nilai dan mengenali peluang, Kemampuan komunikasi; Mobilitas manusia dan sumber daya berpengaruh positif dan signifikan terhadap Kinerja aparatur pemerintah. Hasil penelitian juga menunjukean sikap Inovator merupakan variabel yang terendab nilainya, untuk itu pimpinan daerah sebaiknya meningkatkan sikap Inovator para pegawai, baik melalui pelatihan kepemimpinan, kewirausahaan, atau meningkatkan kualitas pendidikan, sehingga dapat meningkatkan kinerja aparaturpemerintah.
\end{abstract}

Kata kunci: sikap mental enterpreneurial, inovator, menciptakan nilai, kinerja

Received: February 23, 2017; Revised: June 14, 2017; Approved: July 6, 2017 
Entrepreneurial Government Attitude.........

Agus Supandi Soegoto, Ritson Eras Kadisi

\section{INTRODUCTION}

People's demand for the implementation of good governance in the public sector throughout the recent years has increased. This is learned from the experiences of many public organizations that have poor performance. White (2000) argues that the private sector and the public sector face the environmental challenges more or less the same. While the government bureaucracy organization is the organization of the forefront (street level bureaucracy) that provide services to the community (Yusrialis, 2012).

The environmental changes that covers all aspects of life, whether they are economic, social, cultural, and political aspects influences the demands of the community. The determination of the law (UU) No.32 of 2004 and Law No.33 of 2004 concerning regional Governments and Financial Equalization Between the Central Government and the regions, implies a broader autonomy demands and accountability of the public service, in the era of regional autonomy (Idris, 2012).

The quality of public services in Indonesia does not provide satisfaction for the society as users of services. Society as users of services should pay more expensive (high cost economy) for getting the public service. Uncertainty of time and cost make people have a negative perception toward the bureaucracy (Ghina, 2012). While the process of decentralisation was intended to make local governments more effective and responsive to the local population, and may have opened a way to achieve such purposes, serious downsides to decentralisation are also reported. Particularly in developing and transitional countries, monopoly on power by local elites is the frequently reported problem (Charlick, 2001; Devas and Grant, 2003; Litvack et al., 1998; Peters, 2001).

The public sector executive reviews and corrects the ways work, for example by introducing a new system, reorganization, adopting new work methods and so forth including making management changes (Ulupui, 2002). Performance seen from the speed, quality, service and value the meaning of speed in the process of working that have reliable quality and good service and value is seen from the achievement of a performance or not. The public sector also needs to make efficiency and effectiveness in the management by cutting government spending (Walsh, 1995). It shows the current public sector is expected to show the characteristics possessed the private sector, including in the field of entrepreneurial behavior (Leadbetter, 1997 in White, 2000). To meet the challenges that 
arise from changes in the global environment, society today requires a bureaucracy that has the soul of an entrepreneur/ entrepreneurial government (Winarno, 2004).

This is due to the challenges of globalization, both in the context of administrative and political context will never be implemented effectively if local government officials failed to adequately develop its capacity to manage the development process. In this context, it is significant for reinventing government to be applied at the right moment. In this context, reinventing is interpreted as a reinvention of bureaucracy by relying on selfemployment system, which is to create organizations and public systems that are used to updates, continuosly, improve its quality without needing a boost from the outside.

Reinventing means creating a public sector that has the inner urge to correct in a way "that renews the system independently". In other words, make reinventing government is ready to face the challenges that may not be anticipated "economic turbulance". In addition, reinventing not only improve the effectiveness of the current government, but also be able to build organizations that are able to improve its effectiveness in the future at the time of the organization's environment changes rapidly (Osborne and Plastrik, 1992).

There are at least seven competence that must be possessed by entrepreneurial bureaucracy, namely (Winarno, 2004): (1). Sensitive and responsive to new opportunities and challenges that arise in the market; (2). Not fixated on regular activities related to the functions instrumental bureaucracy, but must be able to make a breakthrough (breakthrough) through creative and innovative thinking; (3). Having a futuristic insight and systematic; (4). Having the ability to anticipate, calculate, and pose a risk; (5). Observant of the potential sources and new opportunities; (6). Having the ability to combine resources into a resource that has a mix of high productivity; (7). Having the ability to optimize the available resources, by shifting the source of low productivity activities towards high-productivity activities.

In an era where the market is very dynamic/ volatile, high competition among competitors to capture market share are the same, as a result consumers are becoming accustomed to excellent service, high product quality, plenty of choice and enjoying competitive prices. Such changes have demanded an appropriate response from the organizers of the public bureaucracy (Osborne and Gaebler, 1992), so that the business climate remains conducive for the bureaucrats keen in regulating the market. 
Entrepreneurial Government Attitude.........

Agus Supandi Soegoto, Ritson Eras Kadisi

Sitaro Islands District as a new autonomous region of the division, is currently in full swing carrying out the development in accordance with the spirit of regional autonomy, with the orientation of the progress of regional development that is consistent with national policy, through breakthroughs by both the regional government bodies, the business sector, and the community to absorb the opportunity and build the area so that it does not lag behind other autonomous regions which are divided based on the principles of wealth management area, based on the rules established between the center and regions, with the aim to improve service, and oriented towards improving people's welfare.

The mental attitude of the government apparatus as a bureaucrat, must be changed. Schuller (1990) states without: (1) a good performance in all levels of the organization; (2) the achievement of the objectives; and (3) the success of the organization into something very difficult and even impossible. An understanding of the spirit of service, and work to achieve results allegedly have not been part of the principles in carrying out the work. Yet it is to be a primary reflector, for the entrepreneur's mental attitude. In the workplace behavior, negative traits of government officials are still visible, they are: Employees often come late for work, being absent for no apparent reason, which result in a buildup of work (job late resolved), services administration delays, the reduce of confidence in the local government apparatus, etc. Rachman (2008) states the reform pattern of organization of the public service of the former government as the provider of oriented into serviceoriented community needs as a user. So there is no alternate entrance to start improvements to public services other than as soon as possible to listen to the voice of the public itself.

The negative traits are quite contrary to the opinion of Osborne and Gaebler (1992), among others: 1) competitive government officials and 2) the government apparatus that is driven by the mission (the organization is driven by regulation). The same opinion was delivered (Winarno, 2004) that in order to apply entrepreneurial government, then government officials should have the orientation: 1) Preventing problems before they start. 2) focus the energy to be productive, 3) decentralizing authority 4) Liking market mechanisms rather than bureaucratic mechanisms (dynamic) 5) Catalyzing all acts of public sector, business and the public to attempt to solve the problem. 


\section{METHOD}

The research type is explanatory or is an explanation that is associative to determine the effect of independent variables on the dependent variable. This research is based on the quantitative type of data collected. In this study, the target population is the government apparatus of the Sitaro Islands District with the total sample of 115 civil servants. The research location is in the District of Sitaro Islands. The study was conducted in July to September 2016. The non-probability sampling techniques were used on government officials in the area of Sitaro Islands District, where they have an opportunity and an equal chance to be elected as respondents. In accordance with the characteristics of a particular sample required then the non-probability sampling techniques selected was the purposive sampling technique. Purposive technique is used when the researchers selects a sample based on several criteria (Cooper \& Schindler, 2006).

This study uses the Likert scale as a research instrument. The multiple regression analysis is a method that is used to describe the relationship between the independent variables and the dependent variable. The analysis techniques used in this research is multiple linear regression, with the following formula:

$$
Y=b_{0}+\beta_{1} X_{1}+\beta_{2} X_{2}+\beta_{3} X_{3}+\beta_{4} X_{4}+\beta_{4} X_{4}+\beta_{5} X_{5}+\varepsilon_{t}
$$

$$
\begin{aligned}
& \text { Dimana : } \\
& Y=\text { performance of government officials } \quad X_{5}=\text { Human resources } \\
& X_{1}=\text { Innovator } \quad \beta 0 \quad=\text { Intercept } Y \\
& X_{2}=\text { Courageous and creative attitude } \quad \beta_{1 . .} \beta_{5}=\text { regression coefisient } \\
& X_{3}=\text { Creating value and identifying opportunities } \quad \varepsilon=\text { Error or gallat } \\
& X_{4} \quad=\text { Communication skills. }
\end{aligned}
$$
mobility

\section{RESULT AND DISCUSSION}

The test results of the research instruments are all valid and reliable. All items are valid questions having a value above the value of $r_{\text {count }} r_{\text {table }}$, and also the value of $r$ is greater than the critical value that is above $0.30(>0.30)$. While the reliability test shows all variables are reliable because it has Cronbach alpha values above the value of 0.60 or $>$ 0.60 (Malhotra, 2007). The test results shows that all variables in this study are valid and reliable, and may be continued for the multiple linear regression analysis and hypothesis testing. Multicolinearity test results can be seen in Table 2 . 
Entrepreneurial Government Attitude.........

Agus Supandi Soegoto, Ritson Eras Kadisi

Multicollinearity test results shows that VIF (Variable Inflation Factor) is between 1 to $10(<10)$, thus it can be concluded there is no symptoms of multicollinearity between independent variables. Heteroscedasticity Test results shows that the dots randomly spread and spread both above and below the number 0 on the $\mathrm{Y}$ axis. It can be concluded that there is no heteroscedasticity. It also shows no patterns formed, in other words, the graph illustrates plots spread. Normality test conducted shows that the distribution of the data gathered around the test line leads to the upper right. No data were located away from the distribution of the data, so the normal distribution of data is concluded.

Tabel 2. Multicollinearity Test

\begin{tabular}{lll}
\hline Model & VIF & Resullt \\
\hline Innovator $\left(\mathrm{X}_{1}\right)$ & 2,321 & Non multicolinearity \\
Courageous and Creative Attitude $\left(\mathrm{X}_{2}\right)$ & 5,712 & Non multicolinearity \\
Creating Value and Identifying & 4,999 & Non multicolinearity \\
Opportunities $\left(\mathrm{X}_{3}\right)$ & 1,130 & Non multicolinearity \\
Communication Skills $\left(\mathrm{X}_{4}\right)$ & 1,604 & Non multicolinearity \\
Human Resources Mobility $\left(\mathrm{X}_{5}\right)$ & 2,321 & Non multicolinearity \\
The performance of government officials & & \\
$(\mathrm{Y})$ & & \\
\hline
\end{tabular}

Sumber: Data processed (2016)

Multiple Regression Analysis is a statistical technique that simultaneously develops a mathematical relationship between two or more independent variables and an intervalscaled dependent variable.

Tabel 3. Multiple Regression Result

\begin{tabular}{|c|c|c|c|c|c|c|c|}
\hline Variable & $B$ & \multicolumn{2}{|c|}{ Standard Error } & Beta & $T_{\text {count }}$ & Sig. & Result \\
\hline Constant & 12,411 & \multicolumn{2}{|c|}{1,669} & & 7,434 & 0,000 & \\
\hline $\mathrm{X}_{1}$ & 0,102 & \multicolumn{2}{|l|}{0,136} & 0,102 & 2,215 & 0,001 & Significant \\
\hline $\mathrm{X}_{2}$ & 0,113 & \multicolumn{2}{|l|}{0,196} & 0,131 & 2,577 & 0,000 & Significant \\
\hline $\mathrm{X}_{3}$ & 0,121 & \multicolumn{2}{|l|}{0,104} & 0,126 & 2,591 & 0,000 & Significant \\
\hline $\mathrm{X}_{4}$ & 0,167 & \multicolumn{2}{|l|}{0,174} & 0,191 & 1,903 & 0,000 & Significant \\
\hline $\mathrm{X}_{5}$ & 0,106 & \multicolumn{2}{|l|}{0,101} & 0,107 & 2,055 & 0,000 & Significant \\
\hline \multicolumn{2}{|c|}{$\mathrm{R}$ (Multiple $\mathrm{R})$} & $=$ & 0,228 & & & & \\
\hline \multicolumn{2}{|c|}{ R Square } & $=$ & 0,116 & & & & \\
\hline \multicolumn{2}{|c|}{ R Square (Adjusted) } & $=$ & 0,029 & & & & \\
\hline \multicolumn{2}{|c|}{ F count } & $=$ & 9,363 & & & & \\
\hline \multicolumn{2}{|l|}{ Sig. F } & $=$ & 0,001 & & & & \\
\hline \multicolumn{2}{|l|}{$\mathrm{t}_{\text {tabel }}$} & $=$ & \multicolumn{5}{|c|}{$1,658(\mathrm{n}=115 ; 0,05)$} \\
\hline \multicolumn{2}{|l|}{$\alpha$} & $=$ & \multicolumn{3}{|c|}{$0,05(5 \%)$} & & \\
\hline
\end{tabular}

Source: Data processed (2016) 
Based on the data in Table 3, the multiple regression equation can be formulated as follows:

$$
\mathrm{Y}=12,411+0,102 \mathrm{X}_{1}+0,113 \mathrm{X}_{2}+0,121 \mathrm{X}_{3}+0,167 \mathrm{X}_{4}+0,106 \mathrm{X}_{5}
$$

The value of $\mathrm{R}$ is 0.228 indicating a substantial positive association between independent and dependent variable. R Square value of 0.116 in this study may imply that the contribution of Innovator, Courageous and Creative Attitude, Creating Value and Identifying Opportunities, Communication Skills and Human Resources Mobility to Performance of government officials $11.6 \%$ while the remaining $88,4 \%$ is affected by other variables not examined in this study.

The $\mathrm{F}_{\text {test }}$ results on Table $3, \mathrm{~F}_{\text {count }}=9,363$ with a significance level of 0.001 . In this research, $\mathrm{F}_{\text {count }}>\mathrm{F}_{\text {table }}\left(\mathrm{F}_{\text {count }}\right.$ is greater than $\left.\mathrm{F}_{\text {table }}\right)$, then the regression model of $\mathrm{F}_{\text {test }}$ can be 9,363>1,658 that means $\mathrm{H}_{0}$ is rejected and $\mathrm{H}_{1}$ is accepted. The regression model can be used to declare that the independent variable of $\mathrm{X}_{1}$ (Inovator), $\mathrm{X}_{2}$ (Courageous and Creative Attitude), $\mathrm{X}_{3}$ (Creating Value and Identifying Opportunities), $\mathrm{X}_{4}$ (Communication Skills) and $\mathrm{X}_{5}$ (Human Resources Mobility) affects the dependent variable $\mathrm{Y}$ (The performance of government officials). In conclusion, since the value $\mathrm{F}_{\text {count }}>\mathrm{F}_{\text {table }}$ means that $\mathrm{Ho}$ is rejected and $\mathrm{H}_{1}$ is accepted, meaning that entrepreneurial government mental attitude simultaneously affect the performance of the government apparatus.

A significance level of 0.05 was used and the output obtained was $t_{\text {calculate }}$ equal to 2.215. The distribution $t_{\text {table }}$ be sought at a $=5 \%$ (Test 2 sides) with degrees of freedom $\mathrm{df}$ $=113$, with 2 -sided test (significance $=0.025$ ) the results obtained for $t_{\text {table }}$ of 1.658. Obtained $t_{\text {count }}>t_{\text {table }}(2.215>1.658)$ Ho is rejected. The conclusion is because $t_{\text {count }}>t_{\text {table }}$ then Ho is rejected, it means that innovator has partial effect on the performance of the government apparatus. $\mathrm{T}$ value is positive, meaning that the effect is positive, meaning that the higher the value of Innovator further improve the performance of government officials. Variable Innovator also has a significance less than 0.05 , that is 0.001 , meaning the variable Innovator has a significant influence on the performance of the government apparatus.

A significance level of 0.05 was used and the output obtained was $t_{\text {count }} 2,577$. The distribution table $\mathrm{t}$ be sought at $\mathrm{a}=5 \%$ (Test 2 sides) with degrees of freedom $\mathrm{df}=113$, with 2 -sided test (significance $=0.025$ ) the results obtained for $t_{\text {table }}$ of 1.658. Obtained $\mathrm{t}_{\text {count }}>\mathrm{t}$ table $(2.577>1.658)$ Ho is rejected. The conclusion is because $\mathrm{t}_{\text {count }}>\mathrm{t}_{\text {table }}$ then Ho 
Entrepreneurial Government Attitude..........

Agus Supandi Soegoto, Ritson Eras Kadisi

is rejected, it means that Courageous and Creative has partial influence on the performance of government officials. $T$ value is positive, meaning the influence that occurs is positive, so the more courageous and creative the employees, the higher the performance of government officials. Variable Courageous and creative also has a significance influence less than 0.05 , that is 0.000 , meaning variable Courageous and creative significantly influence the performance of the government apparatus.

A significance level of 0.05 was used and the output obtained was $t_{\text {count }} 2,591$. The distribution table $\mathrm{t}$ be sought at $\mathrm{a}=5 \%$ (Test 2 sides) with degrees of freedom $\mathrm{df}=113$, with 2-sided test (significance $=0.025)$ the results obtained for $\mathrm{t}_{\text {table }}$ of 1.658. Obtained $\mathrm{t}_{\text {count }}$ $>t_{\text {table }}(2.591>1.658)$ Ho is rejected. The conclusion because $t_{\text {count }}>t_{\text {table }}$ then Ho is rejected, it means that the variable Creating value and opportunity is recognized as having partial influence on government officials performance. $\mathrm{T}$ value is positive, meaning the influence that occurs is positive, so the higher the nature of Creating value and opportunity increases the performance of government officials. Variable creating value and opportunity also has a significance influence less than 0.05 , which is 0.000 , meaning variable Creating value and opportunity has signoficant influence on the government officials performance.

A significance level of 0.05 was used and the output obtained was $t_{\text {count }} 1,903$. The distribution table $\mathrm{t}$ be sought at $\mathrm{a}=5 \%$ (Test 2 sides) with degrees of freedom $\mathrm{df}=113$, with 2-sided test (significance $=0.025$ ) the results obtained for $\mathrm{t}_{\text {table }}$ of 1.658. Obtained $\mathrm{t}_{\text {count }}$ $>t_{\text {table }}(1.903>1.658) H 0$ is rejected. The conclusion is because $t_{\text {count }}>t_{\text {table }}$ then Ho is rejected, it means that variable Communication partially influences government officials performance. $T$ value is positive, meaning influence that occurs is positive, so that the higher the skills of communication, the government officials performance increases. Variable Communications also has a significance influence less than 0.05 , which is 0.000 , meaning variable Communication Skills significantly influences government officials performance.

A significance level of 0.05 was used and the output obtained was $t_{\text {count }} 2,055$. The distribution table $\mathrm{t}$ be sought at $\mathrm{a}=5 \%$ (Test 2 sides) with degrees of freedom $\mathrm{df}=113$, with 2-sided test (significance $=0.025$ ) the results obtained for $t_{\text {table }}$ of 1.658. Obtained $t_{\text {count }}>t_{\text {table }}(2.055>1.658)$ Ho is rejected. The conclusion because $t_{\text {count }}>t_{\text {table }}$ then Ho is rejected, it means that the variable Mobility human resources partially influences government officials performance. $T$ value positive, meaning the influence that occurs is positive, so the higher the mobility of human resources the better the performance of 
government officials. Variable Human Resources Mobility also has a significance influence less than 0.05 , which is 0.000 , meaning variable Mobility human resources has significant effects on the performance of government officials.

This study uses the multiple linear regression analysis to see each of the relationship between independent variables and dependent variable. Then, to obtain a valid test of the regression analysis the classical assumption is performed. The result of the classic assumption test conducted are namely: normality is met, there is no multicollinearity, there are no heteroscedasticity. It can be concluded that the regression model was valid. The test results are then inserted into the multiple regression equation, in the form of a formula.

The research concludes that entrepreneural mental attitude, such as; innovators, courageous and creative attitude, creating value and identifying opportunities, communication skills and mobility human resources have positive influence on the performance of government officials simultaneously. Hypothesis test results show the entrepreneurial mental attitude has significant effect on the performance of government officials. In the interpretation, the greater the entrepreneurial mental attitude, the better the effect on the performance of government officials in the Sitaro Islands District. These results show that our model can serve as a model to predict the performance of the civil state apparatus, namely Innovators, Courageous and creative attitude, Creating value and identifying opportunities, Communication Skills, and mobility of human resources.

Interpretation of the results of this study affirms that the entrepreneurial mental attitude comprising Innovators attitude, Courageous and creative attitude, Creating value and identifying opportunities, Communication skills and Mobility of human resources simultaneously influence the performance of government officials. This result also shows the percentage contribution (coefficient of determination) of independent variables, entrepreneurial mental attitude has contributed positively to performance of government officials or variation of independent variables used in the model is able to explain the variation of the independent variables. The rest was influenced by other variables not included in this research model.

Partially it is known that: Innovators attitude influences the performance of government officials. T value is positive, meaning that the effect occuring is positive, so the higher the attitude of innovators will further increase the performance of the government 
Entrepreneurial Government Attitude..........

Agus Supandi Soegoto, Ritson Eras Kadisi

apparatus. Innovators also has a attitudinal variables influence, the significance is less than 0.05 is 0.001 , meaning it has significant effect on Performance of the government apparatus. This is according to research of Ikhsan (2007); Sumarhadi (2002) who found that the entrepreneurial mental attitude, for instance Innovators, affect the performance of the civilian state apparatus. Sunarso (2010) states when a person has a entrepreneurial equipped mental attitude, then he will be ready to plunge into the business world because it has an attitude ready to look for opportunities, compete and even able to win the competition.

Courageous and creative attitude is a courageous behaviour which accepts the risk of doing work and making decision. The results shows Courageous and creative attitude influences the government officials performance. $T$ value is positive, meaning that the effect occuring is positive, so the higher the Courageous and creative attitude will further enhance the performance of the government apparatus. Variable Courageous and creative attitude also has a significance less than 0.05 is 0.000 , meaning the variable significantly influences the government officials performance. This means that employees in Siau, Tagulandang and Biaro Islands District are ready to weigh and accept the risk in decisionmaking.

Creating value and recognizing opportunities is the ability to create something of value and identify profitable opportunities. The variable Creating Value Recognizing Opportunity has influence on the performance of government officials. T value is positive, meaning that the effect occuring is positive, so the higher the Creating value and identifying opportunities attitude will further increase the performance of the government apparatus. Variable Creating value and Recognizing opportunity also has a significance less than 0.05 , which is 0.000 , meaning it has significant influence in the government officials performance.

This result means that the employees in Siau, Tagulandang and Biaro Islands District are ready to create something of value and identify profitable opportunities. These results are consistent with studies Ikhsan (2007); Sumarhadi (2002) who found that the Entrepreneurial Mental Attitude, such as Creating value and identify opportunities, influences the performance of the civilian state apparatus. Ghina (2012) stated that employees already have the high potential to be entrepreneurial which is very supportive to the success of the organization in the future. 
Communication Skills has influence on the performance of government officials. T value is positive, meaning that the effect occuring is positive, so the higher the ability of communication will further increase the performance of the government apparatus. Variable Communication Skills also has a significance less than 0.05, which is 0.000 , meaning it has significant influence on the government officials performance. Likewise, Mobility human resources has influence on the performance of government officials. T value is positive, meaning that the effect occuring is positive, so the higher the mobility of Human resources will further enhance the performance of the government apparatus. The variable Human resources mobility also has a significance less than 0.05 , which is 0.000 , meaning it significantly influences the government officials performance.

Entrepreneurial government (government-oriented entrepreneurs) will always be able to present a policy-oriented citizens. The policies taken has strategic value because it will generate returns in the form of increased support from the lead. Mahsun (2006) states to accelerate and magnification of dividends in the form of support from constituents is a necessity in public service and presenting problem solving regulation so that the agency can focus on three main tasks are: to respond to complaints of its citizens quickly, conduct a routine inspection, and punish who violate the regulations. The main focus of attention on entrepreneurial government is how to think strategically to broaden the perspective and take advantage of the creativity that is responsible, besides that they are not only able to generate brilliant ideas, but also accompanied by the ability to realize those ideas. Government apparatus-oriented entrepreneurs, will be able and willing to take risks that are scalable and able to explain the steps that are considered strange and innovative (Mahsun, 2006; Sumarhadi, 2002).

\section{CONCLUSION}

The enterpreneurial mental attitude is very important for the government apparatus, so that in conducting their duties and job, they are no longer oriented toward cultural centralization, structuralization, formalization and apathy, but oriented on innovation, daring and creative attitude, ability to create value and identify opportunities, skills of communication, and capability of human resources mobility and resources organization. In the context of the interaction strategies between supervisors, peers, subordinates or employees who have a high entrepreneurial mental attitude, 
Entrepreneurial Government Attitude.........

Agus Supandi Soegoto, Ritson Eras Kadisi

will always perform their tasks and job oriented toward empowering, the principles of partnership, functionalization in organization and democratization.

The results shows that both simultaneously and partially, the five independent variables of entrepreneurial mental attitude namely: Innovators, Courageous and creative attitude, Creating value and identifying opportunities, Communication skills and Mobility of human resources have positive and significant impact on the performance of government officials in Sitaro Islands District. Attitude towards Innovator (innovation capacity) employees in the District of Sitaro Islands are still low. Therefore the leadership of the local government in the Sitaro Islands District should improve the innovators attitude of their employees, either through training of leadership, entrepreneurship, or improving the quality of their education, so by increasing Innovators attitude they may improve the performance of employees in the Sitaro Islands District.

\section{REFERENCES}

Charlick, R. B. (2001) Popular Participation and Local Government Reform. Journal Public Administration and Development. 21: 149-157.

Cooper, D.R. \& Schindler, P.S. (2006). Business Research Methods, $9^{\text {th }}$ Edition. New York: McGraw Hall, Irwin.

Devas, N. \& Grant, U. (2003) Local Government Decision--Making- Citizens Participation and Local Accountability: Some Evidence from Kenya and Uganda. Journal Public Administration and Development. 23: 307-316.

Ghina, Astri (2012) Corporate Entrepreneurship at Public Service Sector: Measurement and the Influence toward Government Performance. International Journal of Basic and Applied Science. 1 (1): 22-32.

Idris, A. (2012). Pengaruh Motivasi Kerja dan Jiwa Kewirausahaan Terhadap Kinerja Pelayanan Aparatur SKPD dan Implikasinya Pada Kualitas Pelayanan Publik di Provinsi Aceh (The Effect of Working Motivation and Entrepreneurial Intention to Service Performance of SKPD Official and Its Implication to Public Service Quality in Aceh). Jurnal Ekonomika. Vol. III (5): 301-312.

Ikhsan, A. (2007). Mencari Variabel yang Mempengaruhi Sikap Mental Entrepreneurial Pemerintah Kabupaten (Finding The Variables that Affect the 
Entrepreneurial Mental Attitude of District Government). Manajemen Usahawan Indonesia. 36 (8): 3-19.

Litvack, J., Ahmad, J. \& Bird, R. (1998). Rethinking Decentralization in Developing Countries. Washington DC: The World Bank.

Malhotra, N.K. (2007). Marketing Research an Applied Orientation. New Jersey: Pearson Education International.

Mahsun, M. (2006). Pengukuran Kinerja Sektor Publik (The Measurement of Public Sector Performance. Yogyakarta: BPFE.

Osborne, D. \& Plastrik, P. (1992). Banishing Bureucracy. New York: Addison-Wesley.

Osborne, D. \& Gaebler, T. (1992). Reinventing Governement: How the Entrepreneurial Spirit is Transforming the Public Sector. New York: Penguin Book, Ltd.

Peters, G. B. (2001). The Future of Governing. Kansas: The University Press of Kansas.

Rachman, M. (2008). Reformasi Pemerintahan Daerah Dalam Membangun Model Pelayanan Publik Yang Dapat Memenuhi Keinginan Masyarakat (Local Government Reformation to Built a Public Service Model that Can Fulfill the People's Wants). Jurnal PREDIKSI. 7 (4):1-12.

Schuller, R.S. (1990). Repotitioning The Human Resources Function: Transformation or Demise. Academy of Management Perspective. 4 (3): 49-60.

Sumarhadi. (2002). Entrepreneurial Government dalam Persepsi Pejabat Birokrasi Pemerintah: Studi Kasus pada Pemerintah Daerah Kabupaten Bengkalis (Entrepreneurial Government in Bureaucratic Officials Perception: Case Study in Bengkalis District). (Unpublished Thesis). Yogyakarta: Universitas Gadjah Mada.

Sunarso. (2010). Sikap Mental Wirausahawan dalam Menghadapi Perkembangan Zaman (Mental Attitudes of Entrepreneurs Facing the Development of the Age). Jurnal Ekonomi dan Kewirausahaan. 10 (2): 151-170.

Ulupui, IG.K.A. (2002). Petunjuk Menuju Penilaian Kinerja Pada Sektor Publik (Guidance Toward Performance Assessment of The Public Sector). Jurnal Akuntansi dan Kenangan Sektor Publik, 3 (1): 10-16.

Walsh, K. (1995). Public Service and Market Mechanism. London: Macmillan.

White, L. (2000). Changing the Whole System in The Public Sector. Jurnal of Organizational Change Management. 13 (2): 162-177. 
Winarno, B. (2004). Implementasi Konsep "Reinventing Government" dalam Pelaksanaan Otonomi Daerah (Implementation of the Concept "Reinventing Government" in the Implementation of Regional Autonomy. Paper in Bureaucratic Arrangements in the Implementation of Regional Autonomy. Dialogue JIAKP. 1 (2): 175-197.

Yusrialis. (2012). Budaya Birokrasi Pemerintahan: Keperihatinan dan Harapan (Culture of Government Bureaucracy: Concern and Hope. Jurnal Sosial Budaya. 9 (1): 81-108. 